University of Nebraska - Lincoln

DigitalCommons@University of Nebraska - Lincoln

6-1-2005

\title{
Effect of Bio-Optical Parameter Variability on the Remote Estimation of Chlorophyll-a Concentration in Turbid Productive Waters: Experimental Results-Erratum
}

Giorgio Dall'Olmo

Oregon State University, giorgiod@science.oregonstate.edu

Anatoly A. Gitelson

University of Nebraska - Lincoln, agitelson2@unl.edu

Follow this and additional works at: https://digitalcommons.unl.edu/natrespapers

Part of the Natural Resources and Conservation Commons

Dall'Olmo, Giorgio and Gitelson, Anatoly A., "Effect of Bio-Optical Parameter Variability on the Remote Estimation of Chlorophyll-a Concentration in Turbid Productive Waters: Experimental Results-Erratum" (2005). Papers in Natural Resources. 261.

https://digitalcommons.unl.edu/natrespapers/261

This Article is brought to you for free and open access by the Natural Resources, School of at DigitalCommons@University of Nebraska - Lincoln. It has been accepted for inclusion in Papers in Natural Resources by an authorized administrator of DigitalCommons@University of Nebraska - Lincoln. 


\title{
Effect of bio-optical parameter variability on the remote estimation of chlorophyll-a concentration in turbid productive waters: experimental results - erratum
}

\author{
Giorgio Dall'Olmo and Anatoly A. Gitelson
}

In the original publication [Dall'Olmo and Gitelson, Appl. Opt. 44, 412 (2005)], certain information was presented inaccurately. These inaccuracies are corrected here. (C) 2005 Optical Society of America

OCIS codes: $\quad 010.4450,280.0280$.

In the original paper by Dall'Olmo and Gitelson, ${ }^{1}$ please note the following corrections. On page 417, left column, last two lines: "as high as a factor of $1 \%$ and $10 \%$, respectively. ${ }^{22,45 " ~ s h o u l d ~ r e a d ~ " a s ~ h i g h ~ a s ~ a ~}$
On page 420, Table 4, the first and third band combinations (column 1) are incorrect. Also, the $a_{0}$ coefficient for Gons, 1999 is not significant. The corrected Table 4 follows:

Table 4. Results of the Model Validation ${ }^{a}$

\begin{tabular}{|c|c|c|c|c|c|c|}
\hline Band Combination & $\begin{array}{c}a_{0} \\
(\mathrm{STE})\end{array}$ & $\begin{array}{c}a_{1} \\
\text { (STE) }\end{array}$ & $\begin{array}{l}\text { RMSE of [Chla] Prediction } \\
\left(\mathrm{mg} \mathrm{m}^{-3}\right)\end{array}$ & RMS & $\mathrm{RMS}_{>10}$ & $r^{2}$ \\
\hline$R_{r s}^{-1}(673) R_{r s}(735)$ & $-8(3)$ & $0.99(0.04)$ & 13.7 & 0.40 & 0.30 & 0.91 \\
\hline$R_{r s}^{-1}(665) R_{r s}(725)$ & $-9(3)$ & $1.04(0.04)$ & 14.2 & 0.47 & 0.36 & 0.91 \\
\hline$\left[R_{r s}^{-1}(671)-R_{r s}^{-1}(710)\right] R_{r s}(740)$ & - & $0.93(0.03)$ & 15.1 & 0.45 & 0.25 & 0.88 \\
\hline$R_{r s}{ }^{-1}(675) R_{r s}(705)$ & $-13(5)$ & $1.31(0.08)$ & 28.3 & 0.71 & 0.48 & 0.84 \\
\hline Reflectance height & $13(4)$ & $0.55(0.06)$ & 28.5 & 0.48 & 0.43 & 0.57 \\
\hline Gons, 1999 & - & $2.31(0.16)$ & 77.1 & 0.77 & 0.76 & 0.74 \\
\hline
\end{tabular}

${ }^{a} a_{0}$ and $a_{1}$ are the intercepts and slopes (with corresponding standard errors in brackets), respectively, of the best linear fits between observed and predicted [Chla] values. RMSE is the root-mean-squared error. RMS is the relative RMSE; RMS $>10$ is the RMS computed excluding stations with $[\mathrm{Chla}]<10 \mathrm{mg} \mathrm{m}^{-3}$. Slopes in bold were significantly different from one $(p<0.05)$. Only intercepts significantly different from zero $(p<0.05)$ were included. The number of samples was 58 .

factor of 2 and $10 \%$, respectively. ${ }^{22,45 \%}$

The authors are with the Center for Advanced Land Management Information Technologies, School of Natural Resources, University of Nebraska-Lincoln, 113 Nebraska Hall, Lincoln, Nebraska 68588-0517. G. Dall'Olmo's e-mail address is gdall@calmit.unl.edu.

Received 25 January 2005; accepted 25 January 2005.

0003-6935/05/163342-01\$15.00/0

(C) 2005 Optical Society of America
On page 420 , left column, second paragraph, line two, "(1.33)" should read "(1.31)"; line five, "( $p$ $>0.05)$ " should read " $(p<0.05)$ "; line six, "the RMS $\sim 0.48$ " should read "the RMS $\sim 0.71$."

\section{Reference}

1. G. Dall'Olmo and A. A. Gitelson, "Effect of bio-optical parameter variability on the remote estimation of chlorophyll-a concentration in turbid productive waters: experimental results," Appl. Opt. 44, 412-422 (2005). 